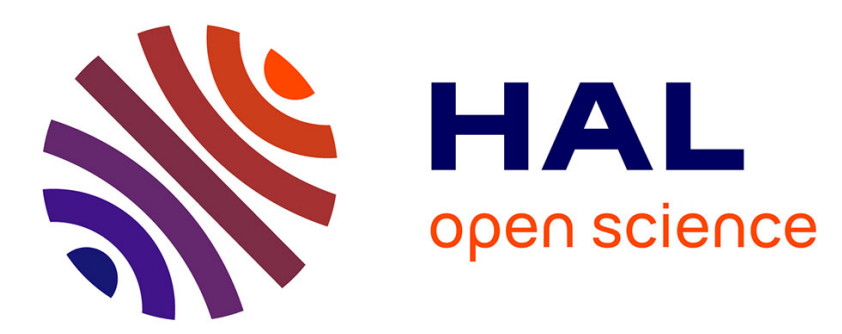

\title{
Influence of forest road, road surfacing material and stand age on floristic diversity and composition in a nutrient-poor environment
}

L. Bergès, Richard Chevalier, C. Avon

\section{- To cite this version:}

L. Bergès, Richard Chevalier, C. Avon. Influence of forest road, road surfacing material and stand age on floristic diversity and composition in a nutrient-poor environment. Applied Vegetation Science, 2013, 16 (3), p. 470 - p. 479. 10.1111/avsc.12019 . hal-00844904

\section{HAL Id: hal-00844904 \\ https://hal.science/hal-00844904}

Submitted on 16 Jul 2013

HAL is a multi-disciplinary open access archive for the deposit and dissemination of scientific research documents, whether they are published or not. The documents may come from teaching and research institutions in France or abroad, or from public or private research centers.
L'archive ouverte pluridisciplinaire HAL, est destinée au dépôt et à la diffusion de documents scientifiques de niveau recherche, publiés ou non, émanant des établissements d'enseignement et de recherche français ou étrangers, des laboratoires publics ou privés. 
Author-produced version of the article published in Applied Vegetation Science, 2013, 16, 3, 470-479

Original publication available at http://onlinelibrary.wiley.com/

doi : 10.1111/avsc.12019

version auteur corrigée

Influence of forest road, road surfacing material and stand age on floristic diversity and composition in a nutrient-poor environment

Laurent Bergès, Richard Chevalier \& Catherine Avon

Bergès, L. (Corresponding author, laurent.berges@ @irstea.fr) \& Avon, C.

(catherine.avon@irstea.fr): Irstea, UR EMAX, 3275 Route de Cézanne, CS 40061, 13182

Aix-en-Provence Cedex 5, FR

Chevalier, R. ( richard.chevalier@irstea.fr): Irstea, UR EFNO, Domaine des Barres, 45290

Nogent-sur-Vernisson, France 


\section{ABSTRACT}

Questions. How did the presence of forest roads modify plant diversity and composition in a nutrient-poor environment? What was the effect of the use of limestone gravel as road surfacing material? How did floristic succession vary between roadside and forest interior?

Location. State Forest of Orléans, Loiret, Northern France.

Methods. We sampled thirty pairs of $2000-m^{2}$ plots, one on road and the other $30 \mathrm{~m}$ inside forest, on two road surfacing materials (limestone gravel and bare soil) and three stand ages (young, middle-aged, and mature) in Scots and Corsican pine stands in a large managed forest. Plant diversity was analysed according to life-history traits (protection status, indigenousness, life form, habitat and ecological preferences). We tested the effects of plot position, road type and stand age on species richness, species composition and individual species response.

Results. The species richness of all plant groups was always higher on roads compared to forest stands, and the forest plot communities were nearly completely nested within the roadside plot communities. Seven protected species and four non-native potentially invasive species were observed on roadsides. Limestone gravelled roads hosted more species than bare soil roads, but acidophilous forest and grassland species richness was higher on bare soil roads. Plant composition similarity between the roadside and forest were higher at early successional stages and lower in older stages.

Conclusions. Roads have inseparable positive and negative effects on plant communities, but the negative ones are of great concern. To prevent further damage in these nutrient-poor ecosystems, we recommend monitoring road sections hosting protected acidophilous species, not increasing road density, and replacing limestone gravel by a low-pH endogenous material.

Key words: Forest road impact; Limestone material; Neophyte; Protected species; 
Author-produced version of the article published in Applied Vegetation Science, 2013, 16, 3, 470-479 Original publication available at http://onlinelibrary.wiley.com/

doi : 10.1111/avsc.12019

Succession; Soil alkalinisation.

Nomenclature: French BDNFF flora nomenclature (Tela-Botanica, 2011).

\section{Abbreviations:}

LGR: limestone-gravelled road

BSR: bare soil road

Running head: Limestone-gravelled forest road effect on plants 


\section{INTRODUCTION}

Transportation infrastructures are now considered a major driver of biodiversity loss (e.g., Spellerberg 1998; Trombulak \& Frissell 2000; Forman et al. 2003; Benitez-Lopez et al. 2010). Reported impacts from roads include habitat loss, intrusion of edge effects in natural contiguous areas, new habitat creation, isolation of native species populations, road mortality and increased human access (e.g., Trombulak \& Frissell 2000; Forman et al. 2003). For plants, the main road effects consist of disturbance during construction and pollution from both the road material and the subsequent road traffic (Angold 1997; Godefroid \& Koedam 2004). In particular, the use of alkaline gravel for road building and maintenance can have strong and long-lasting environmental effects, especially in nutrient-poor environments (Farmer 1993; Godefroid \& Koedam 2004; Mullerova et al. 2011). The soil and vegetation of the nearby habitats can be modified due to lateral transport of particles by road dust and water runoff (Farmer 1993; Angold 1997; Mullerova et al. 2011). The accumulation of lime and clay substrates can also increase $\mathrm{pH}$, nutrient content, soil moisture and bulk density and thus facilitate roadside invasion of exotic and nitrophilous species (Greenberg et al. 1997; Johnston \& Johnston 2004). Despite the obvious concern for forest habitats, there have been few investigations into the impact of alkaline materials used for road construction and maintenance (Godefroid \& Koedam 2004; Dziadowiec et al. 2006). Most of the relevant work has focused on the effect of liming on forest soils and understory vegetation (Rodenkirchen 1992; Dulière et al. 1999, Misson et al. 2001). Limestone-gravelled forest roads in acid environments are reported to create locally neutral-to-alkaline conditions at the roadsides and in adjacent habitats (Godefroid \& Koedam 2004).

In addition, road management generally implies light conditions, frequent vegetation mowing and soil disturbances, all of which favour open-habitat, ruderal, exotic and more competitive species (Parendes \& Jones 2000; Buckley et al. 2003; Watkins et al. 2003) and thus 
potentially increase total species richness. However, this increase may mask a decrease or loss of bryophytes, stress-tolerant species and other slow-growing species on roadsides (Avon et al. 2010), as these species are unable to grow in disturbed environments with sparse canopy cover and are likely to be replaced by more competitive species (Angold 1997; Buckley et al. 2003; Mullerova et al. 2011). Differences between roadsides and forest according to species richness, species composition and plant traits must be examined in depth in order to fully evaluate the trade-off between positive and negative effects of forest roads.

Roadside conditions change with adjacent forest stand development, and light conditions, soil disturbance and vegetation mowing frequency all decrease with stand age (Avon et al. 2010). Previous investigations suggested that ruderal and non-forest species colonized from road verges into forest interior in young stands following regeneration cutting, while forest species displayed the reverse pattern in adult stands once the canopy closed above the forest road (Avon et al. 2010). It is assumed that disturbances and light conditions would be similar in roadsides and recently-regenerated stands but different in mature stands and roadsides bordering mature stands. Consequently, we can assume a higher floristic similarity in young roadside and the adjacent stand interior compared to corresponding mature roadside and stand interior. A second hypothesis would be that distinct floristic successions occur in forest and roadside due to persistent differences in ecological conditions, disturbance regimes and soil seed bank.

Following previous investigations (Avon et al. 2010), our concern was to study how forest road modifies understory plant biodiversity in a nutrient-poor environment, with three specific goals:

(1) to compare plant species richness, composition and traits between roadside and forest interior to evaluate the contribution of roads to global plant diversity of forests;

(2) to assess the effect of limestone gravel as road surfacing material on plant diversity in a 
nutrient-poor environment;

(3) to compare floristic succession between roadside and forest interior.

\section{MATERIALS AND METHODS}

\section{Study sites}

The study was conducted in the State Forest of Orléans $\left(48^{\circ} \mathrm{N}, 2^{\circ} \mathrm{E}\right)$, an ancient forest sensu Hermy et al. (1999), that covers about 35000 ha. Elevation ranges from 107 to $174 \mathrm{~m}$, climate is oceanic, and mean annual precipitation is about $700 \mathrm{~mm}$. The study sites were located in the eastern part of the forest, named "Massif de Lorris" (Fig. 1), in even-aged high forests mainly derived from plantations with Scots pine (Pinus sylvestris L.) or Corsican pine (Pinus nigra subsp. laricio var. Corsicana). Soils were acidic ( $\mathrm{pH} \mathrm{H}_{2} \mathrm{O}$ range: 3.7 to 5.3), sandy loams or sandy in surface with high clay content at a depth of 20 to $70 \mathrm{~cm}$ and moderate to severe temporary waterlogging.

\section{Sample design and data collection}

We selected 30 forest stands bordering roads mostly closed to public traffic (except four), where two road surfacing materials and three stand age classes were crossed in a balanced design. We selected 15 roads improved with limestone gravel for forest machinery and logging truck traffic, termed limestone-gravelled roads (LGR), and 15 bare soil roads, i.e. keeping natural soil (BSR, see Appendix S1). The limestone gravel layer could reach several tens of centimetres, and intense reaction with hydrochloric acid $(\mathrm{HCl})$ was systematically detected on the road verge. LGR width averaged $15.1 \pm 2.2 \mathrm{~m}$ and was significantly larger than BSR width which averaged $12.8 \pm 1.8 m(t=3.07, D F=26.5, P=0.005)$. Three stand age classes were sampled in each road type: 10 young stands (1-6 $\mathrm{m}$ in height), 10 middle-aged stands (9$15 \mathrm{~m}$ ), and 10 mature stands (>20 m, see Appendix S1). Mature stands were mixed with 
broadleaves, mainly Quercus petraea Matt. Liebl.

In each of the 30 sites, we sampled two $2000-\mathrm{m}^{2}$ plots, one along the road and one at $30 \mathrm{~m}$ from the road edge inside the forest stand. We methodically sampled all the microhabitats from one edge to the other edge (road, verges, ditches and embankments, see Appendix S1). Since road width varied, we had to adjust plot length. Plot width varied between 11 and 17.5 $m$ and corresponding plot length between 114.3 and $181.8 \mathrm{~m}$. The paired plot in forest had the same dimensions as the road plot.

The same person recorded the percent cover of each individual understory vascular plant species between 0 and $2 m$ height. Plots were visited once between May and September 2011 . In total, 292 species were inventoried.

\section{Species traits}

Life span and Raunkiaer's life form data was compiled from Biolflor (Kühn et al. 2004) and three groups were considered: annuals/biennial, perennial herbs and woody species (shrubs and trees). Species were also classified according to habitat preferences following Julve (2011) and we focused on acidic grassland and forest preferences. Other habitat preferences were not analysed (crop, mesophilous grassland, wet grassland and heathland). Indicator values of species abiotic preferences for light (L), soil reaction (R), soil nitrogen $(\mathrm{N})$ and soil humidity (F) were obtained from Ellenberg et al. (1992). Protection status was also considered (Appendix S2): we identified 5 species (Ajuga occidentalis, Arnica montana, Genista germanica, Oreoselinum nigrum, Osmunda regalis) with a regional protection status (protected in the "Centre" administrative region of France), two of which (Arnica montana, Genista germanica) were classified as being at critical risk of extinction in the list of threatened species (Cordier 2010). Two other species (Nardus stricta, Simethis mattiazzi) were classified as vulnerable. These seven species were pooled into a group called "protected 
species". Four neophytes considered potentially invasive or requiring particular attention were identified (Appendix S2): Conyza canadensis, Juncus tenuis, Erigeron annuus and Matricaria discoidea.

\section{Data analyses}

Species richness split by plant traits were computed at plot scale (Appendix S3). Preliminary analyses did not find difference between forest plots according to type of adjacent road (LGR or BSR). We thus simplified the original sample design structure and compared forest, BSR and LGR plots (this factor was hereafter termed "position").

First, we ran ANOVA models (aov function of R sofware) to test the effects of position and stand age (young, middle-aged and mature) and their interaction on the species richness of all the ecological groups, except protected and invasive species. All the effects were treated as factors. Residuals were checked for normality and heteroscedasticity. Tukey multiple comparisons of means were applied to the ANOVA model in order to determine which position were significantly different with a $95 \%$ family-wise confidence level (TukeyHSD function). Tukey tests were applied while controlling for the other factor differences. Since the range of species richness for protected species and invasive species was narrow (0-3), we simply considered the presence of the group in each plot and thus applied a logistic regression to this variable using the same predictors as above ( $g \operatorname{lm}$ function). The alternative logistic models were compared using Akaike's information criterion (AIC) using a threshold of $\operatorname{delta}(A I C)=2$ to select the best model (AIC function).

Second, the effect of position and stand age on plant community composition was examined using a canonical correspondence analysis (CCA) using the $c c a$ function in the ade4 package. We analyzed the 182 species present in at least four plots out of the 292 species collected, as it is not recommended to apply CCA with sporadic species. We conducted permutation tests 
to test the effects of the two factors and their interaction using the anova.cca function in the vegan package with 2000 permutations $(P<0.001)$.

Third, we applied linear regressions to analyze the effect of position and stand age and their interaction to the cover of the 182 plants of the CCA ( $\operatorname{lm}$ function). A probability threshold of $P=0.01$ was used to keep only the most significant responses. To respect this probability threshold, the alternative logistic models were compared using AIC with a threshold of $\operatorname{delta}(A I C)=5$ to select the best model.

Statistical analyses were performed using R software (version 2.12.1, R Foundation for Statistical Computing, Vienna, AT).

\section{RESULTS}

\section{Species richness of ecological groups}

Species richness was well explained by the two factors and always significantly richer on roads compared to forests (Table 1, Fig. 2 and 3). The species richness ratio between forest and roads was over 2.8 for acidic grassland species, annual/biennial species, perennial herbs and species with indicator value of $\mathrm{R}>6, \mathrm{~N}>6, \mathrm{~F}>6, \mathrm{~F}<4$ and $\mathrm{L}>7$. The species richness ratio between forest and roads was under 2.3 for the other ecological groups: forest, woody species, and species with indicator values of $\mathrm{R}<4$ and $\mathrm{L}<5$. At least one protected species was detected in $67 \%$ of the road plots against just $3 \%$ of forest plots, and neophytes were only present on roads.

Species richness was higher on BSR than LGR for acidic grassland species and species with an indicator value of R<4 (Fig. 3). Conversely, species richness was higher on LGR for forest species, perennial herbs and species with indicator values of $\mathrm{R}>6$ and $\mathrm{N}>6$.

The effect of stand age was significant for eight ecological groups: protected species, acidic grassland species, annual/biennial species, perennial herbs, woody species, and species with 
indicator values of $\mathrm{R}<4, \mathrm{~F}<4$ and $\mathrm{L}>7$. There was also a significant interaction between position and stand age for acidic grassland species and perennial herbs whereas an interaction without main effect for age was observed for forest species and species with indicator values of $\mathrm{N}>6, \mathrm{~F}>6$ and $\mathrm{L}<5$. Four patterns were observed considering forest succession (Fig. 2 and 3): (1) the first pattern corresponded to a relatively regular decrease from young to mature stands and occurred for acidic grassland species, annual/biennial species, and species with indicator values of $\mathrm{R}<4, \mathrm{~F}<4$ and $\mathrm{L}>7$; (2) the second pattern corresponded to a decrease in species richness from young to mature stands in forest plots but an increase in road plots (forest species, species with indicator values of $\mathrm{N}>6, \mathrm{~F}>6$ and $\mathrm{L}<5$ ); in particular, the species richness of forest species and shade-tolerants $(\mathrm{L}<5)$ was similar in young forests and young roadsides and then decreased in forests but increased on roadsides; (3) woody species and perennial herbs showed a decrease in forests but almost no change on roadsides; (4) protected species were more frequent in middle-aged stands.

\section{Plant species composition}

The CCA applied to the floristic matrix of 60 sites x 182 species showed that $31.2 \%$ of the total variance was explained by position, stand age and their interaction. The correlations between the constraints and the first three factorial axes were $R^{2}=0.95,0.89$ and 0.79 , respectively. Permutation tests showed that the factorial axes, main effects and interaction were all highly significant $(P<0.001)$. The first and second axes displayed a pronounced arch effect, and separated forests from LGR, with BSR in an intermediate position (Fig. 4a). The second and third axes discriminated among young, middle-aged and mature plots in each position (forest, LGR and BSR, Fig. 4b).

\section{Individual species response}


The cover of 96 species was influenced by position, stand age and/or their interaction (Appendices S4 to S6): the cover of 89 species significantly responded to at least position, 16 species responded to at least stand age, and 11 displayed a significant interaction between the two factors. A total of 35 and 53 species were significantly more abundant on BSR and LGR, respectively. Only Molinia coerulea was more abundant in forest plots (Appendix S4). Five species, one of which is protected, were absent from LGR: Aira praecox, N. stricta, Rumex acetosella, Tuberaria guttata and Veronica serpyllifolia. Symmetrically, six species were absent from BSR: Agrimonia eupatoria, Festuca arundinacea, Galium verum, Picris hieracioides, Polygala vulgaris and Ranunculus flammula. Among the 16 species with a significant main age effect (Appendix S5), 12 were more abundant in young stands, three were more abundant in mature stands and one (Polygala vulgaris) displayed a non-monotonic pattern. The patterns of the 11 species with a significant interaction were heterogeneous (Appendix S5): five species were more abundant in young stands on roads but absent or very rare in forest.

\section{DISCUSSION}

\section{The contribution of roads to the overall plant biodiversity of forests}

Roadside communities were always species-richer than forest control plots. However, the positive road effect was much lower for forest plants that are sensitive to disturbance and competition and adapted to this nutrient-poor environment (shade-tolerant, acidophilous and woody species), and this positive road effect was also age-dependent. A few species were restricted to forest plots, and only $M$. caerulea significantly preferred the forest interior. Eighty-eight species were more abundant on roadsides and half of them $(n=43)$ were also present in forest interior. These results are consistent with previous investigations (Forman \& Alexander 1998; Buckley et al. 2003; Godefroid \& Koedam 2004; Avon et al. 2010; 
Baltzinger et al. 2011) but the main difference was the very low number of species preferably or exclusively present in the forest interior (cf. Watkins et al. 2003; Avon et al. 2010). The nested communities we observed between roads and forest interior could be related to the sampling method adopted. We inventoried all the microhabitats of the road (verge, ditch and embankment) which offer a large panel of suitable conditions for plants (Wrobel, 2006). We previously identified a high species richness including a large number of forest species at the forest edge (Avon et al. 2010). Here, we assigned the species specific to the embankment position as species specific to road, while Avon et al. (2010) considered the embankment as a specific habitat at the interface between forest and road. Moreover, bryophytes were not inventoried in this study, whereas Avon et al. (in press) found that bryophytes were negatively affected by road proximity and preferred forest interior.

Roadside communities are composed of forest generalists enriched with forest edge species and grassland species. These species are annual or biennial, shade-intolerant and sometimes nitrogen-demanding, and thus adapted to low tree competition and frequent soil disturbances by vehicles, forest machinery and vegetation mowing (Buckley et al. 2003). Roadsides were also found to be suitable habitats for several species with a protection status. This suggests that in landscapes dominated by intensive agricultural practices (as was the case here), forest road verges can offer favourable refuges for typical open-habitat flora threatened by agricultural practices (Peterken \& Francis 1999; Smart et al. 2002; Cousins \& Lindborg 2008).

However, four neophytes were also inventoried on roadsides but were never observed $30 \mathrm{~m}$ inside forest interior, which adds support to the role of roads as prime habitats and conduits for alien plant species (Parendes \& Jones 2000; Gelbard \& Belnap 2003; Flory \& Clay 2006; Kalwij et al 2008; Christen \& Matlack 2009; Joly et al. 2011; Gasso et al. 2012). The concomitant presence of protected and alien species on roads means that positive and negative 
roles of forest roads are somehow impossible to separate. However, neophytes had little cover in our study and cannot be considered as invasive. The low neophyte cover could reflect a low colonization and poor habitat suitability in this environment, as observed for Ambrosia artemisifolia in Québec (Joly et al. 2011). Indeed, our sites were located far from the external forest edge (distance to edge averaged $1400 \mathrm{~m}$ ) and were thus less submitted to human influence. The study was located in an ancient forest (continuous forest land use since at least the early $19^{\text {th }}$ century), a habitat less favourable to invasion compared to recent forests on former agricultural soils (Kuhman et al. 2011).

\section{Role of limestone gravel as road surfacing material in a nutrient-poor environment}

First, our results underlined that road surfacing material was a strong determinant of plant diversity and composition, and that composition dissimilarity was higher between LGR and forest plots than between BSR and forest plots. Limestone-gravelled roads favoured many basophilous and nitrogen-demanding species but were detrimental to acidophilous species (including acidic grassland species). Limestone-gravelled roads in acidic environments created locally neutral-to-alkaline conditions in the roadsides that can extent to adjacent habitats (cf. Godefroid \& Koedam 2004). Moreover, the negative effects of LGR on acidophilous plants may go beyond the road to spread into forest interior (Avon et al. in press). Limestone-gravelled roads could thus play a role as barrier for forest acidophilous species more than roads on natural soil, and that may lead to the fragmentation of their populations. Neophyte species richness did not differ between road types, and Juncus tenuis significantly even preferred bare soil roads. Thus, our study did not show evidence that road surfacing material itself facilitates the introduction of non-native species, in contrast with previous observations (Greenberg et al. 1997; Johnston \& Johnston 2004; Mullerova et al. 2011). However, considering that neophytes are dispersed by vehicles and logging machines 
i.e. by agestochory (Von der Lippe \& Kowarik 2007; Veldman \& Putz 2010) but dispersal events are still recent, it could be too early to detect strong differences between road types in terms of habitat suitability. Consequently, forest managers should pay more attention to the difference between limestone-gravelled and bare soil roads.

Second, our results also showed that many species and ecological groups did not exhibit significant differences between road types: this suggests that these groups of plants were not primarily determined by road surfacing material but rather by a combination of drivers including traffic level, roadside vegetation mowing, drainage ditch cleaning, adjacent stand management and agestochory (Spellerberg 1998; Truscott et al. 2005; Ebrecht \& Schmidt 2008).

\section{Floristic succession on roadside and in forest interior}

Our study highlighted that plant response patterns also varied with successional age.

Understory plant composition similarity was higher in young forest interior and roadsides but decreased in older stands, which agrees with our first hypothesis. Plant succession in forest plots was in agreement with previous patterns (Howard \& Lee 2003; Widenfalk \& Weslein 2009). The decreasing availability of light, nutrients, and water together with decreasing frequency in understory vegetation and soil disturbances combine to reduce resource availability for non-forest and forest species and lead to local plant species extinction and continuous decrease in species richness (Gondard \& Deconchat 2003; Roberts 2004; Spyreas \& Matthews 2006).

On roadsides, forest succession also led to canopy closure above the road and subsequently altered roadside ecological conditions. Since the understory vegetation is slower to grow, roadsides are mowed less often in older stands, which accentuates differences between young and older roadsides. However, the succession pattern on roadsides differed from the initial 
floristic model observed in forest interior and was in accordance with previous investigations. In particular, the increase in forest species richness and decrease in grassland species we observed were similar to the patterns reported by Avon et al. (2010). Our results also confirm a two-way dynamic between road verges and forest interior during succession: during the regeneration felling phase, ruderal, short-lived, light-demanding and non-forest species colonised from the adjacent road and from surrounding open-habitat sources into the forest interior of young stands (Charbonneau \& Fahrig 2004). During succession, these groups are progressively extirpated from the forest interior (at least above-ground) due to increasing adverse ecological conditions. Conversely, forest and shade-tolerant species were penalised by the habitat conditions in the interior of mature stands but were able to colonize the road verge at the edge of these stands, due to intermediate light conditions and moderate disturbance. This ecological process was not totally validated in a previous work (Avon et al. 2010) because early post-regeneration felling phases were missing.

Discrepancies in succession patterns among studies could be due to differences in forest soil characteristics and tree species composition. Our stands were mainly composed of Corsican or Scots pines but sessile oak in Avon et al. (2010); this implies less dense canopy cover especially in mature pines (Augusto et al. 2003) and could explain the increase of shadetolerant species during roadside succession, since shade-tolerant could have their optimum in intermediate canopy cover.

\section{MANAGEMENT IMPLICATIONS}

Forest roads hosted a more diverse flora than forest interior and can act as refugia for grassland and protected species in landscapes dominated by intensive agricultural practices. However, the positive effect of the road was less visible for typical forest plants sensitive to high disturbances. Not just grassland but especially neophyte species have been found on 
forest roads that could then facilitate their penetration into forest interior. This function as conduit of introduced species has already been demonstrated by Buckley et al. (2003) and Godefroid \& Koedam (2004). In the perspective of increasing socio-economic pressure on wood resources in temperate forests, forest road density and traffic are expected to increase. A deeper assessment of road effects on biodiversity is required together with long-term monitoring in order to gain a robust cost-benefit analysis of road infrastructure. The use of alkaline road surfacing material has already deeply modified roadside communities by irreversibly increasing soil $\mathrm{pH}$, thus favouring basophilous and nitrophilous species that are actually very rare in the surrounding forests and pushing out acidophilous forest plants. To prevent further damage in these nutrient-poor ecosystems, we recommend monitoring on roadside vegetation and replacing limestone gravel by an endogenous low-pH material (Godefroid \& Koedam 2004; Mullerova et al. 2011).

\section{ACKNOWLEDGMENTS}

Funding was provided by the French Ministry of the Environment (MEDDE) through an Irstea -DEB framework agreement (2009-2011, No. 25). We also thank two anonymous reviewers and Martin Hermy for their valuable comments on the manuscript.

\section{REFERENCES}

Angold, P.G. 1997. The impact of a road upon adjacent heathland vegetation: effects on plant species composition. Journal of Applied Ecology 34: 409-417.

Augusto, L., Dupouey, J.L. \& Ranger, J. 2003. Effects of tree species on understory vegetation and environmental conditions in temperate forests. Annals of Forest Science 60: 823-831.

Avon, C., Bergès, L., Dumas, Y. \& Dupouey, J.L. 2010. Does the effect of forest roads extend 
a few meters or more into the adjacent forest? A study on understory plant diversity in managed oak stands. Forest Ecology and Management 259: 1546-1555.

Avon, C., Dumas, Y. \& Bergès, L. in press. Management practices increase the impact of roads on plant communities in forests . Biological Conservation

DOI:10.1016/j.biocon.2012.10.008.

Baltzinger, M., Archaux, F., Gosselin, M. \& Chevalier, R. 2011. Contribution of forest management artefacts to plant diversity at a forest scale. Annals of Forest Science 68: 395406.

Benitez-Lopez, A., Alkemade, R. \& Verweij, P.A. 2010. The impacts of roads and other infrastructure on mammal and bird populations: a meta-analysis. Biological Conservation 143: $1307-1316$

Buckley, D.S., Crow, T.R., Nauertz, E.A. \& Schulz, K.E. 2003. Influence of skid trails and haul roads on understory plant richness and composition in managed forest landscapes in Upper Michigan, USA. Forest Ecology and Management 175: 509-520.

Charbonneau, N.C. \& Fahrig, L. 2004. Influence of canopy cover and amount of open habitat in the surrounding landscape on proportion of alien plant species in forest sites. Ecoscience 11: $278-281$.

Christen, D.C. \& Matlack, G.R. 2009. The habitat and conduit functions of roads in the spread of three invasive plant species. Biological Invasions 11: 453-465.

Cordier, J. 2010. Liste des espèces menacées de la flore de la région Centre. Version validée par le CSRPN le 30 mars 2010. CBNBP Délégation Centre, Orléans, FR.

Cousins, S.A.O. \& Lindborg, R. 2008. Remnant grassland habitats as source communities for plant diversification in agricultural landscapes. Biological Conservation 141: 233-240.

Dulière, J.F., Carnol, M., Dalem, S., Remacle, J. \& Malaisse, F. 1999. Impact of dolomite lime on the ground vegetation and on potential net $\mathrm{N}$ transformations in Norway spruce 
(Picea abies (L.) Karst.) and sessile oak (Quercus petraea (Matt.) Lieb.) stands in the Belgian Ardenne. Annals of Forest Science 56: 361-370.

Dziadowiec, H., Paszek, I. \& Cereficki, R. 2006. Plant cover and properties of upper soil horizons in road/forest ecotones in Gorzno-Lidzbark Landscape Park. Polish Botanical Studies 22: 173-183.

Ebrecht, L. \& Schmidt, W. 2008. Impact of soil seed bank and diaspore transportation by forest machines on the development of vegetation along skid trails. Forstarchiv 79: 91105.

Ellenberg, H., Weber, H.E., Düll, R., Wirth, V., Werner, W. \& Pauliflen, D. 1992. Zeigerwerte von Pflanzen in Mitteleuropa. Scripta geobotanica 18: 1-258.

Farmer, A.M. 1993. The effects of dust on vegetation - a review. Environmental Pollution 79: 63-75.

Flory, S.L. \& Clay, K. 2006. Invasive shrub distribution varies with distance to roads and stand age in eastern deciduous forests in Indiana, USA. Plant Ecology 184: 131-141.

Forman, R.T.T. \& Alexander, L.E. 1998. Roads and their major ecological effects. Annual Review of Ecology and Systematics 29: 207-231.

Forman, R.T.T., Sperling, D., Bissonette, J.A., Clevenger, A.P., Cutshall, C.D., Dale, V.H., Fahrig, L., France, R., Goldman, C.R., Heanue, K., Jones, J.A., Swanson, F.J., Turrentine, T. \& Winter, T.C. 2003. Road ecology: science and solutions. Island Press, Washington.

Gasso, N., Pino, J., Font, X. \& Vila, M. 2012. Regional context affects native and alien plant species richness across habitat types. Applied Vegetation Science 15: 4-13.

Gelbard, J.L. \& Belnap, J. 2003. Roads as conduits for exotic plant invasions in a semiarid landscape. Conservation Biology 17: 420-432.

Godefroid, S. \& Koedam, N. 2004. The impact of forest paths upon adjacent vegetation: effects of the path surfacing material on the species composition and soil compaction. 
Biological Conservation 119: 405-419.

Gondard, H. \& Deconchat, M. 2003. Effects of soil surface disturbances after logging on plant functional types. Annals of Forest Science 60: 725-732.

Greenberg, C.H., Crownover, S.H. \& Gordon, D.R. 1997. Roadside soils: a corridor for invasion of xeric scrub by nonindigenous plants. Natural Areas Journal 17: 99-109.

Hermy, M., Honnay, O., Firbank, L., Grashof-Bokdam, C. \& Lawesson, J.E. 1999. An ecological comparison between ancient and other forest plant species of Europe, and the implications for forest conservation. Biological Conservation 91: 9-22.

Howard, L.F. \& Lee, T.D. 2003. Temporal patterns of vascular plant diversity in southeastern New Hampshire forests. Forest Ecology and Management 185: 5-20.

Johnston, F.M. \& Johnston, S.W. 2004. Impacts of road disturbance on soil properties and on exotic plant occurrence in subalpine areas of the Australian Alps. Arctic Antarctic and Alpine Research 36: 201-207.

Joly, M., Bertrand, P., Gbangou, R.Y., White, M.C., Dube, J. \& Lavoie, C. 2011. Paving the way for invasive species: road type and the spread of common ragweed (Ambrosia artemisiifolia). Environmental Management 48: 514-522.

Julve, P. 2011. Baseflor. Index botanique, écologique et chorologique de la flore de France. Available at http://philippe.julve.pagesperso-orange.fr/catminat.htm. Accessed Sep 2011.

Kalwij, J.M., Milton, S.J. \& McGeoch, M.A. 2008. Road verges as invasion corridors? A spatial hierarchical test in an arid ecosystem. Landscape Ecology 23: 439-451.

Kuhman, T.R., Pearson, S.M. \& Turner, M.G., 2011. Agricultural land-use history increases non-native plant invasion in a southern Appalachian forest a century after abandonment. Canadian Journal of Forest Research-Revue Canadienne De Recherche Forestière 41: 920-929.

Kühn, I., Durka, W. \& Klotz, S. 2004. BiolFlor - a new plant-trait database as a tool for plant 
invasion ecology. Diversity and Distributions 10: 363-365.

Misson, L., de Warnaffe, G.D. \& Jonard, M. 2001. Effects of fertilization on the vascular ground vegetation of European beech (Fagus sylvatica L.) and sessile oak (Quercus petraea (Matt.) Lieb.) stands. Annals of Forest Science 58: 829-842.

Mullerova, J., Vitkova, M. \& Vitek, O. 2011. The impacts of road and walking trails upon adjacent vegetation: Effects of road building materials on species composition in a nutrient poor environment. Science of the Total Environment 409: 3839-3849.

Parendes, L.A. \& Jones, J.A. 2000. Role of light availability and dispersal in exotic plant invasion along roads and streams in the H. J. Andrews Experimental Forest, Oregon. Conservation Biology 14: 64-75.

Peterken, G.F. \& Francis, J.L. 1999. Open spaces as habitats for vascular ground flora species in the woods of central Lincolnshire, UK. Biological Conservation 91: 55-72.

Roberts, M.R. 2004. Response of the herbaceous layer to natural disturbance in North American forests. Canadian Journal of Botany-Revue Canadienne De Botanique 82: 1273 1283

Rodenkirchen, H. 1992. Effects of acidic precipitation, fertilization and liming on the ground vegetation in coniferous forests of Southern Germany. Water Air and Soil Pollution 61: 279-294.

Smart, S.M., Bunce, R.G.H., Firbank, L.G. \& Coward, P. 2002. Do field boundaries act as refugia for grassland plant species diversity in intensively managed agricultural landscapes in Britain? Agriculture Ecosystems \& Environment 91: 73-87.

Spellerberg, I.F. 1998. Ecological effects of roads and traffic: a literature review. Global Ecology and Biogeography 7: 317-333.

Spyreas, G. \& Matthews, J.W. 2006. Floristic conservation value, nested understory floras, and the development of second-growth forest. Ecological Applications 16: 1351-1366. 
Tela-Botanica, 2011. Base de Données Nomenclaturale de la Flore de France (BDNFF, V4.02). Available at http://www.tela-botanica.org/ Accessed Sep 2011.

Trombulak, S.C. \& Frissell, C.A., 2000. Review of ecological effects of roads on terrestrial and aquatic communities. Conservation Biology 14: 18-30.

Truscott, A.M., Palmer, S.C.F., McGowan, G.M., Cape, J.N. \& Smart, S. 2005. Vegetation composition of roadside verges in Scotland: the effects of nitrogen deposition, disturbance and management. Environmental Pollution 136: 109-118.

Veldman, J.W. \& Putz, F.E. 2010. Long-distance dispersal of invasive grasses by logging vehicles in a tropical dry forest. Biotropica 42: 697-703.

Von der Lippe, M. \& Kowarik, I. 2007. Long-distance dispersal of plants by vehicles as a driver of plant invasions. Conservation Biology 21: 986-996.

Watkins, R.Z., Chen, J.Q., Pickens, J. \& Brosofske, K.D. 2003. Effects of forest roads on understory plants in a managed hardwood landscape. Conservation Biology 17: 411-419.

Widenfalk, O. \& Weslien, J. 2009. Plant species richness in managed boreal forests - Effects of stand succession and thinning. Forest Ecology and Management 257: 1386-1394.

Wrobel, M. 2006. Origin and spatial distribution of roadside vegetation within the forest and agricultural areas in Szczecin Lowland (West Poland). Polish Journal of Ecology 54: 137143. 
Author-produced version of the article published in Applied Vegetation Science, 2013, 16, 3, 470-479

Original publication available at http://onlinelibrary.wiley.com/

doi : 10.1111/avsc.12019

\section{SUPPORTING INFORMATION}

Appendix S1. Illustration of the different road type sampled.

Appendix S2. List of the seven species considered as protected and the four species considered as neophytes in our study.

Appendix S3. Summary statistics of the species richness of the ecological groups.

Appendix S4. Table of the 89 plant species with a preference for forest, BSR or LGR.

Appendix S5. Table of the 19 plant species showing significant responses to stand age and/or significant interaction between stand age and position.

Appendix S6. Table of the 86 plant species that did not significantly vary with position or stand age. 


\section{TABLES}

Table 1. Ecological group responses to position (forest vs. limestone-gravelled road vs. bare soil road) and stand age (young, middle-aged, mature), using multiple ANOVAs for species richness of the ecological group and multiple logistic regressions for presence of the ecological group. Significant threshold values are: $* P<0.05$; **: $P<0.01$; ***: $P<0.001$. NS: not significant. The table indicates the adjusted $R^{2}$ of the ANOVA model.

\begin{tabular}{|c|c|c|c|c|}
\hline & Position & Stand age & Interaction & Adj. $R^{2}$ \\
\hline Protected species ${ }^{1}$ & $* * *$ & $* *$ & NS & - \\
\hline Neophyte species ${ }^{1}$ & $* * *$ & NS & NS & - \\
\hline Acidic grassland species & $* * *$ & $* * *$ & $* * *$ & 0.88 \\
\hline Forest species & $* * *$ & NS & $*$ & 0.43 \\
\hline Annuals/biennial species & $* * *$ & $* *$ & NS & 0.77 \\
\hline Perennial herbs & $* * *$ & $*$ & $* *$ & 0.93 \\
\hline Woody species & $* * *$ & $*$ & NS & 0.54 \\
\hline Species with indicator value of $\mathrm{R}<4$ & $* * *$ & $* * *$ & NS & 0.83 \\
\hline Species with indicator value of $R>6$ & $* * *$ & NS & NS & 0.87 \\
\hline Species with indicator value of $N>6$ & $* * *$ & NS & $* *$ & 0.72 \\
\hline Species with indicator value of $F>6$ & $* * *$ & NS & $*$ & 0.66 \\
\hline Species with indicator value of $F<4$ & $* * *$ & $* *$ & NS & 0.55 \\
\hline Species with indicator value of $L>7$ & $* * *$ & $* * *$ & NS & 0.88 \\
\hline Species with indicator value of $\mathrm{L}<5$ & $* * *$ & NS & $*$ & 0.31 \\
\hline
\end{tabular}

\footnotetext{
${ }^{1}$ Logistic regression model applied to presence of the ecological group.
} 
Author-produced version of the article published in Applied Vegetation Science, 2013, 16, 3, 470-479 Original publication available at http://onlinelibrary.wiley.com/

doi : 10.1111/avsc.12019

\section{FIGURES}

Fig. 1. Location of the 30 plot couples (forest vs. road) in the State Forest of Orléans (Loiret,

France).

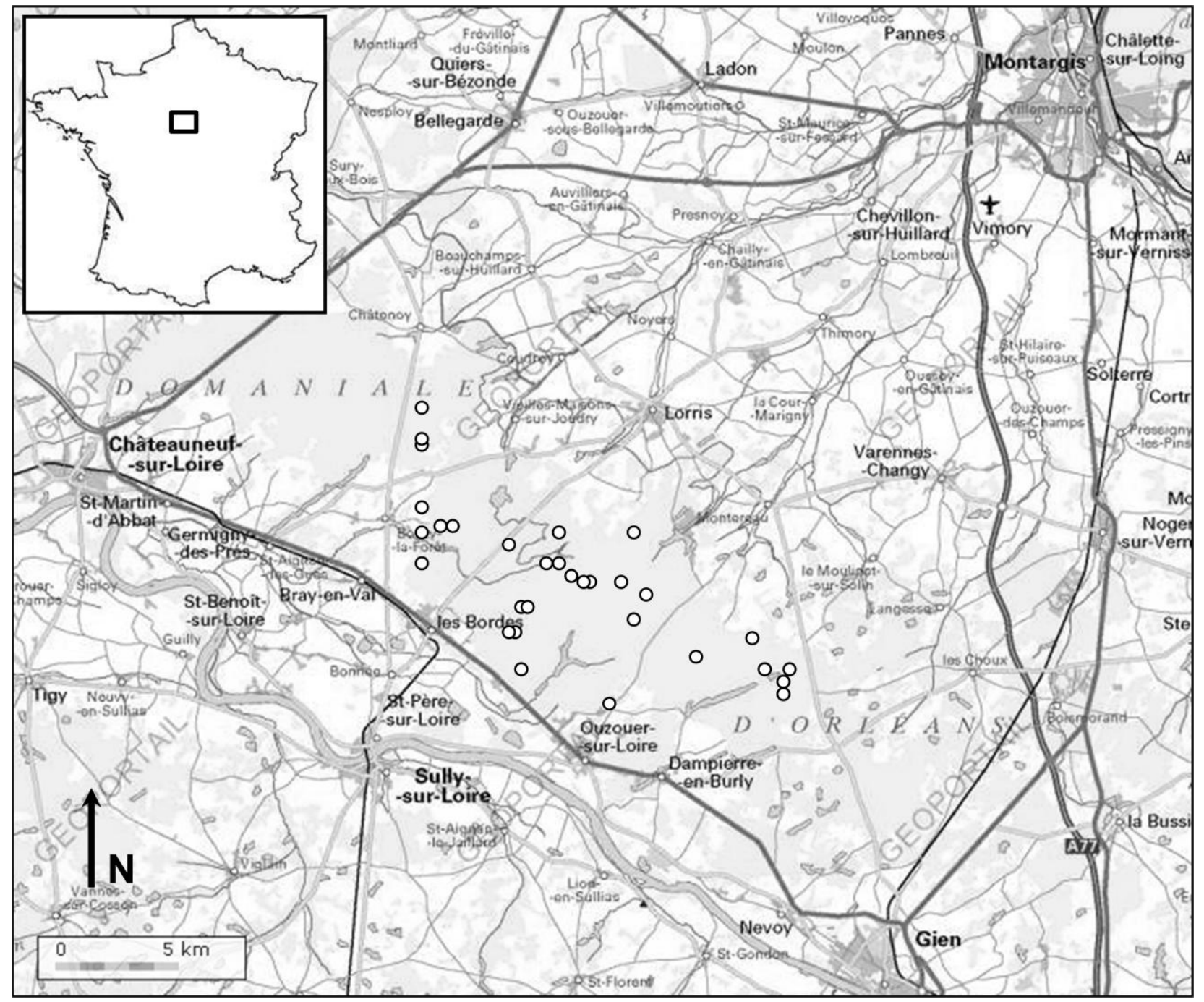


Author-produced version of the article published in Applied Vegetation Science, 2013, 16, 3, 470-479 Original publication available at http://onlinelibrary.wiley.com/

doi : 10.1111/avsc.12019

Fig. 2. Species richness (SR) (or presence) of ecological groups as function of position and stand age: protected species (a), neophytes (b), acidic grassland species (c), forest species (d), annual/biennial species (e), perennial herbs (f) and woody species (g). The graphs give mean and standard deviation for species richness. ANOVA was followed by a Tukey HSD test for unequal sample size; means without common letters differ at $P<0.05$. Abbreviations: FOR: forest plots; LGR: limestone-gravelled roads; BSR: bare soil road; stand ages: YO: young, MI: middle-aged; MA: mature.

a

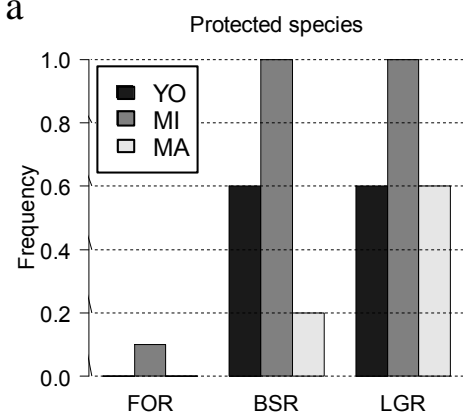

d

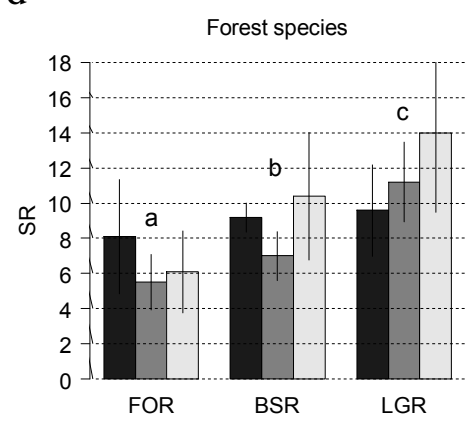

g

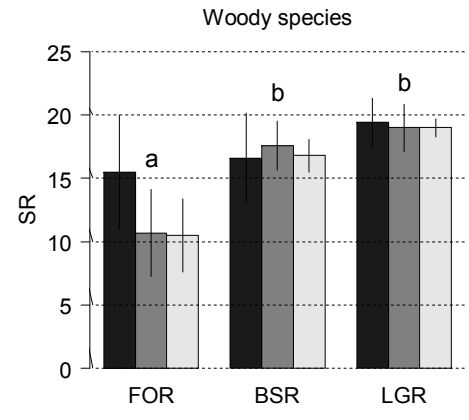

b

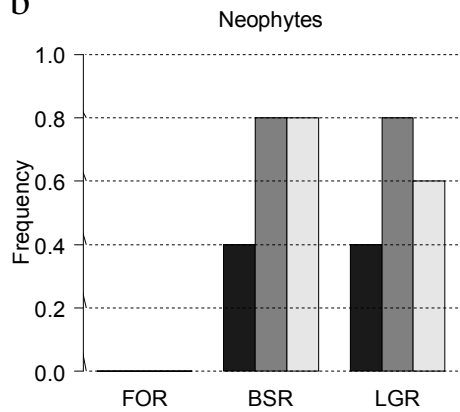

e

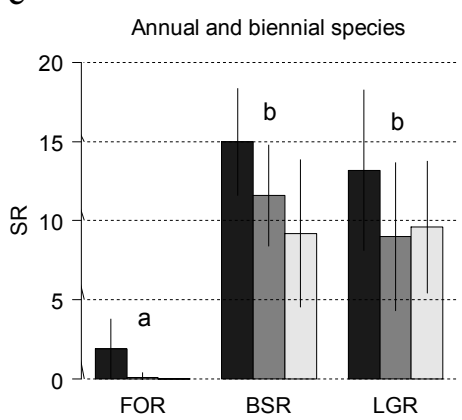

c

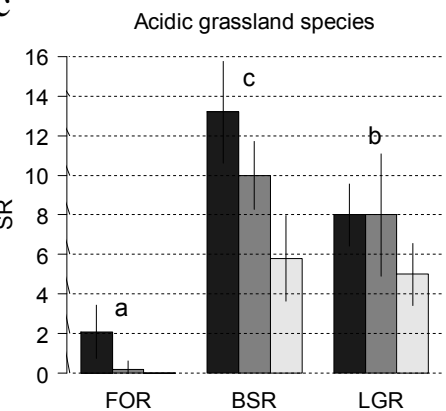

f

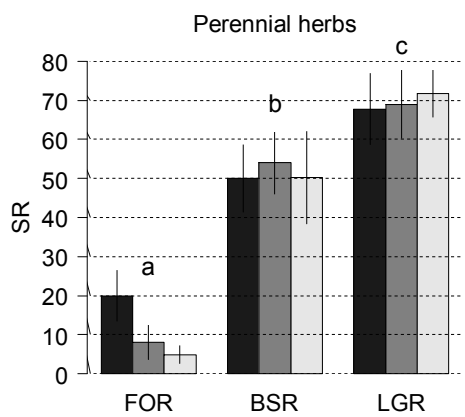


Author-produced version of the article published in Applied Vegetation Science, 2013, 16, 3, 470-479 Original publication available at http://onlinelibrary.wiley.com/

doi : 10.1111/avsc.12019

Fig. 3. Species richness of ecological groups as a function of position and stand age: species with indicator value of $R<4$ (a), species with indicator value of $R>6$ (b), species with indicator value of $N>6$ (c), species with indicator value of $F>6$ (d), species with indicator value of $F<4$ (e), species with indicator value of $\mathrm{L}<5$ (f), species with indicator value of $\mathrm{L}>7$ (g). See Fig. 2 for legend.

a

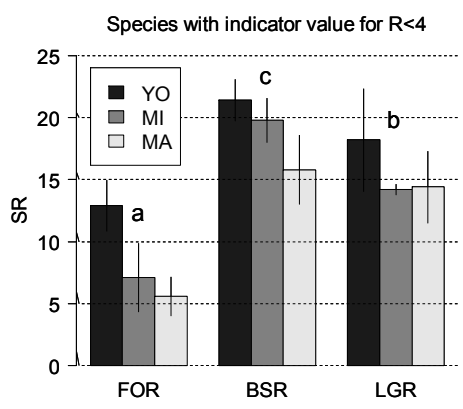

d

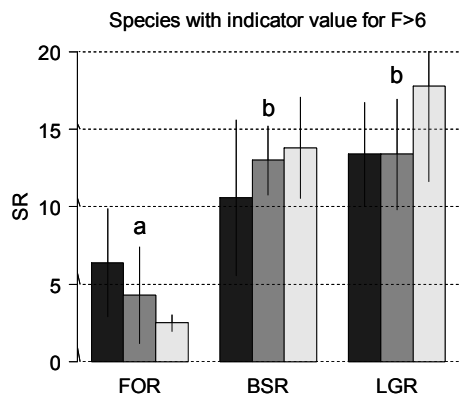

$\mathrm{g}$

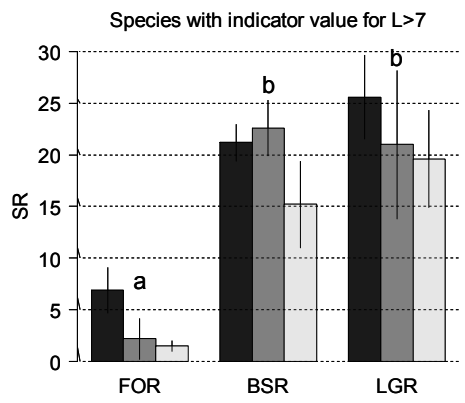

b
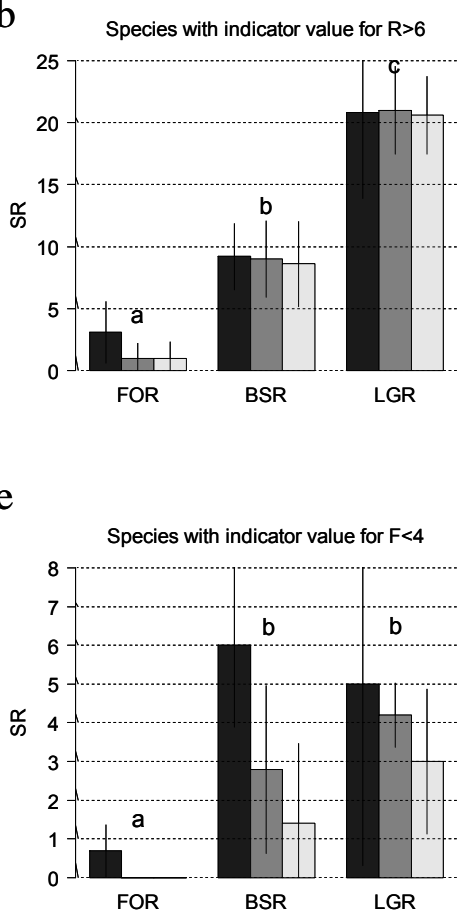

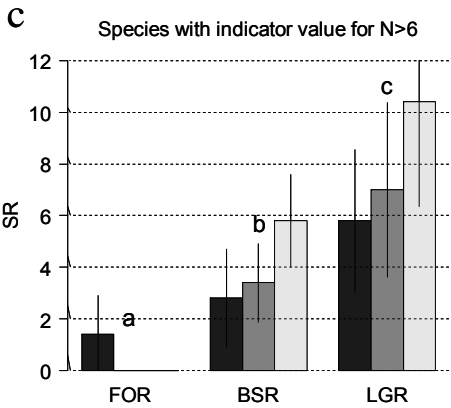

f

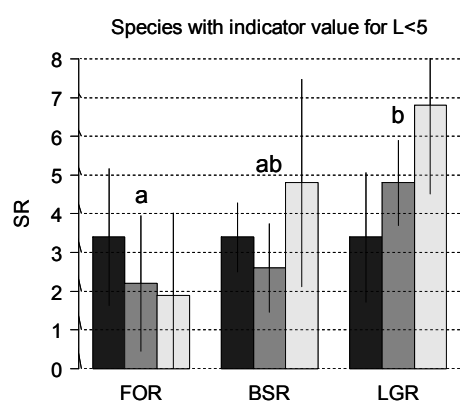


Author-produced version of the article published in Applied Vegetation Science, 2013, 16, 3, 470-479 Original publication available at http://onlinelibrary.wiley.com/

doi : 10.1111/avsc.12019

Fig. 4. Biplot of the relevés in the first factorial map (F1, F2) (a) and the second factorial map $(\mathrm{F} 2, \mathrm{~F} 3)(\mathrm{b})$ of the CCA applied to the matrix of 60 plots and 182 species (species present in at least 4 plots) using position and stand age as predictors. The plots are grouped into 9 classes crossing the two factors: FOR: forest; BSR: bare soil road; LGR: limestone-gravelled road; YO: young stands; MI: middle-aged stands; MA: mature stands. The ellipses indicated that $67 \%$ of the points are inside the ellipse under the hypothesis that the scatter is a simple random sample following a bivariate normal distribution.
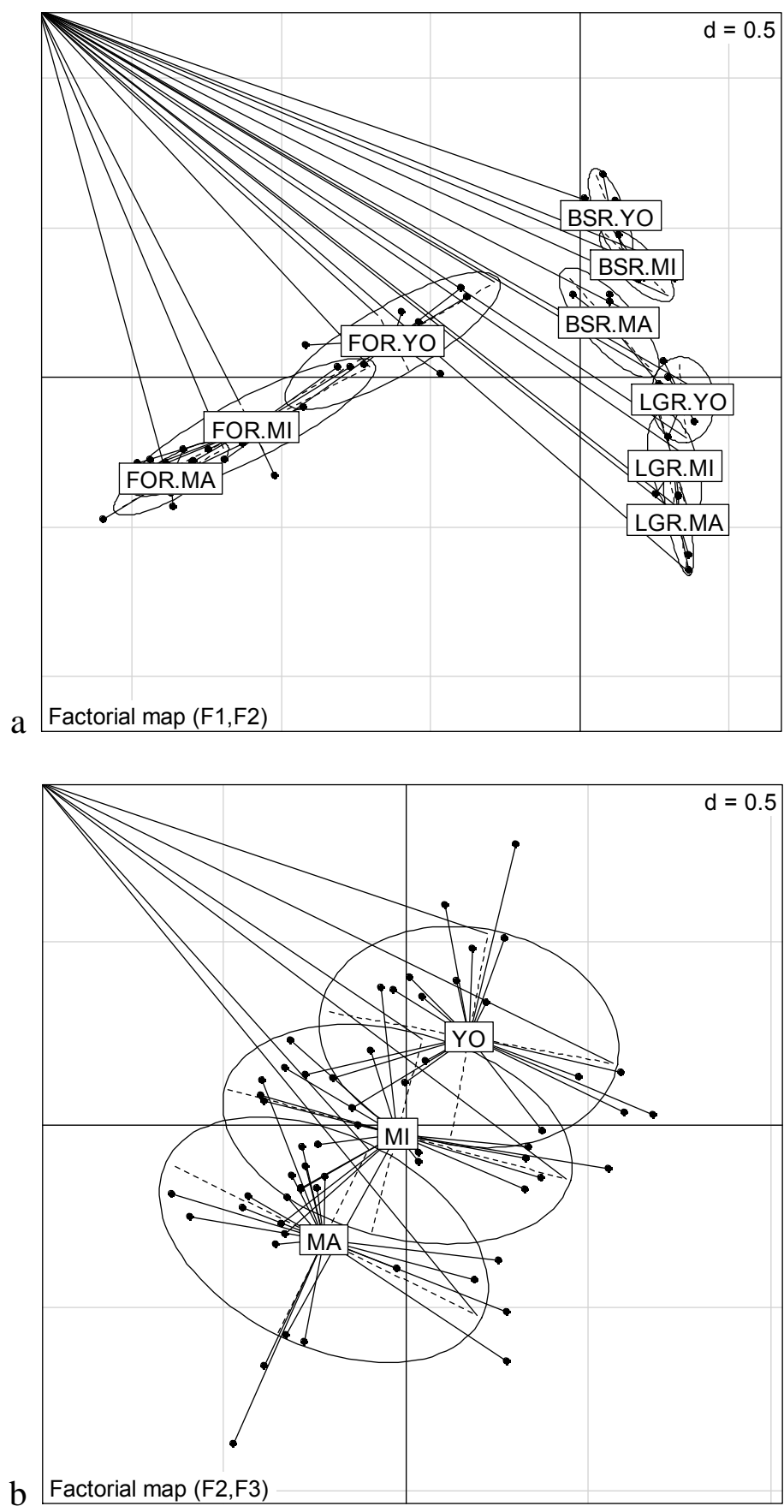